\title{
PERLINDUNGAN HUKUM TERHADAP NASABAH KORBAN DUPLIKASI \\ DATA BANK DI INDONESIA
}

\author{
Dikha Anugrah \\ Fakultas Hukum Universitas Kuningan \\ dikhaanugrah97@gmail.com
}

\begin{abstract}
The role of information technology in all sectors of human life is very important, not least in the banking world. The progress of the banking system cannot be separated from the role of information technology. Various crimes in the world of information technology can also apply to the banking industry, one of which is the duplication of customer data that can harm customers so that customers need to get legal protection. This study aims to determine the legal protection of victims of bank data duplication in terms of Law No. 10 of 1998 concerning Banking and Law No. 11 of 2008 concerning Electronic Information and Transactions.

This research is a descriptive analysis, describing the applicable laws and regulations and relating legal protection to customers from information technology crimes based on banking and ITE laws. The approach method used by the author is a normative juridical approach to understanding, testing, and studying secondary data. Based on the results of the study note that legal protection for victims of data duplication victims based on banking laws has not been discussed in detail, especially in criminal law, while based on the law on information and electronic transactions, legal protection is described in articles relating to misuse of electronic transactions and can be subject to criminal penalties.
\end{abstract}

Keywords: data duplication, skimming, customer protection, banking crime, electronic crime

\section{PENDAHULUAN}

Perbankan sebagai lembaga keuangan mempunyai peran yang sangat strategis dalam kegiatan perekonomian melalui kegiatan usahanya menghimpun dana masyarakat dan menyalurkan pembiayaan bagi usahausaha produktif maupun konsumtif, sekaligus menjadi penentu arah bagi perumusan kebijakan pemerintah di bidang moneter dan keuangan dalam 
mendukung stabilitas pembangunan nasional, khususnya untuk dapat menjadi tempat penyimpanan dana yang aman, tempat yang diharapkan dapat melakukan kegiatan perpembiayaanan demi kelancaran dunia usaha dan perdagangan. ${ }^{1}$

Peran teknologi informasi disemua sektor kehidupan manusia sangat penting tak terkecuali dalam dunia perbankan. Kemajuan sistem perbankan tidak dapat dipisahkan dengan peranan teknologi informasi. Semakin berkembang dan kompleks fasilitas yang diterapkan perbankan untuk memudahkan pelayanan, semakin beragam dan kompleks pula adopsi teknologi yang dimiliki oleh suatu bank. Selain untuk memudahkan operasional internal perusahaan, perangkat teknologi juga bertujuan untuk memudahkan pelayanan terhadap nasabah bank. Karena hampir semua produk yang ditawarkan kepada nasabah itu tidak jauh berbeda, sehingga persaingan yang terjadi dalam dunia perbankan adalah bagaimana memberikan produk yang serba mudah dan cepat. Kegiatan perbankan dengan electronic transaction (e-banking) melalui mesin ATM, telepon seluler (phone banking) dan jaringan internet (Internet banking), merupakan beberapa contoh pelayanan transaksi perbankan dengan teknologi informasi. Dari sisi keamanan, penggunaan teknologi dapat memberi perlindungan keamanan data dan transaksi. ${ }^{2}$

Kejahatan perbankan yang memanfaatkan teknologi informasi sangat beragam. Menurut Kristian istilah-istilah tersebut dikelompokan menjadi dua bagian, kelompok pertama adalah kelompok tindak pidana di bidang perbankan yang pengertiannya sama juga dengan pengertian dari istilah kejahatan di bidang perbankan, tindak pidana terhadap perbankan atau kejahatan terhadap perbankan. Kelompok kedua adalah tindak pidana

\footnotetext{
${ }^{1}$ Teguh Pudjo Mulyono, Manajemen Perkreditan Bagi Bank Komersil, BPFE, Yogyakarta, 2006. Hal. 56

${ }^{2}$ Tim Perundang-Undangan dan Pengkajian Hukum Direktorat Hukum BankIndonesia, "Urgensi Cyberlaw diIndonesia Dalam Rangka Penanganan Cybercrime di Sektor Perbankan", dalam Buletin Hukum Perbankan dan Kebanksentralan, Volume 4 No. 2, Bank Indonesia, Jakarta, 2006.
} 
perbankan yang pengertiannya mencakup pengertian dari istilah kejahatan perbankan. ${ }^{3}$

Tindak pidana perbankan ialah pelanggaran terhadap ketentuan perbankan yang diatur dan diancam dengan pidana berdasarkan Undang No. 10 Tahun 1998 tentang Perbankan. Sementara yang dimaksud dengan tindak pidana di bidang perbankan adalah perbuatan-perbuatan yang berhubungan dengan kegiatan dalam menjalankan usaha pokok bank, perbuatan mana dapat dipidana berdasarkan ketentuan pidana di luar Undang-Undang Perbankan atau undang-undang yang berkaitan dengan perbankan. ${ }^{4}$

Hal kejahatan "pembobolan bank" sendiri seiring dengan perkembangan teknologi yang ada maka timbul perkembangan terkait dengan Modus Operandi yang digunakan. Adapun beberapa jenis Modus Operandi yang kerap dilakukan adalah: 5
a. Pemalsuan Dokumen;
b. Pembukuan ganda;
c. Penggelapan uang nasabah;
d. Mekanisme transfer dana;
e. Pembobolan dengan menggunakan $\mathrm{L} / \mathrm{C} ;{ }^{6}$
f. Phishing (Password harvesting fishing); ${ }^{7}$
g. Cyber Malware; 8
h. Skimming

Salah satu tindak kejahatan yang diangkat dalam penulisan ini adalah duplikasi data nasabah bank atau yang disebut dengan istilah skimming yang merupakan aktivitas menggandakan informasi yang terdapat dalam pita magnetik (magnetic stripe) yang terdapat pada kartu kredit maupun ATM/debit secara ilegal. Ini artinya, dapat disimpulkan bahwa skimming

\footnotetext{
${ }^{3}$ Kristian dan Yopi Gunawan, Tindak Pidana Perbankan, Nuansa Aulia, Bandung, 2013. Hal.14

${ }^{4}$ Sudarto, Kapita Selekta Hukum Pidana, Alumni, Bandung, 1986, Hal.59

${ }^{5}$ Krisna Wijaya, Kejahatan Perbankan dalam Perbankan Nasional Catatan Kolom Demi Kolom, cet. Ke dua (Kompas Media Nusantara 2002). Hal. 38.

${ }^{6}$ Sarah D.L. Roeroe, Perlindungan Terhadap Bank Dalam Transaksi Perdagangan Dengan Menggunakan Sarana Letter Of Credit / LC, XXI Jurnal Hukum UNSRAT, 2013, Hal. 25

${ }^{7}$ Vyctoria, Bongkar Rahasia E-Banking Security dengan Teknik Hacking dan Carding, Andi Offset, Bandung, 2013. Hal. 214

${ }^{8}$ Ferry Satya Nugraha et.,al., Perlindungan Hukum Terhadap Nasabah Bank dalam Pembobolan Internet Banking Melalui metode Malware, edisi 5 Diponegoro Law Jurnal, 2016. Hal. 11.
} 
adalah aktivitas yang berkaitan dengan upaya pelaku untuk mencuri data dari pita magnetik kartu ATM/debit secara ilegal untuk memiliki kendali atas rekening korban. Perbuatan skimming termasuk perbuatan mengakses komputer dan atau sistem informasi milik orang lain dengan cara ilegal dengan maksud mengambil secara ilegal data-data pribadi yang terdapat dalam komputer dan atau sistem informasi tersebut. Perbuatan tersebut termasuk dalam tindak pidana informasi dan transaksi elektornik dan juga termasuk dalam tindak pidana perbankan.

Nasabah tentu dirugikan dengan adanya kejahatan skimming tersebut, lemahnya posisi nasabah selaku konsumen disebabkan antara lain oleh kurangnya pemahaman hukum yang dimiliki oleh mereka, perangkat hukum yang ada belum bisa memberikan rasa aman, dan peraturan-peraturan yang ada kurang memadai untuk secara langsung melindungi kepentingan dan hak-hak nasabah. ${ }^{9}$

\section{RUMUSAN MASALAH}

Dalam penelitian kali ini akan dikemukakan rumusan masalah sebagai berikut:

1. Bagaimana perlindungan hukum terhadap nasabah korban duplikasi data bank ditinjau dari Undang-Undang No. 10 Tahun 1998 Tentang Perbankan?

2. Bagaimana perlindungan hukum terhadap nasabah korban duplikasi data bank ditinjau dari Undang-Undang No. 11 Tahun 2008 Tentang Informasi Dan Transaksi Elektronik?

\section{METODE PENELITIAN}

Metode pendekatan yang digunakan adalah yuridis normatif dengan spesifikasi penelitian adalah deskriptif analitis. Data yang digunakan yaitu

\footnotetext{
9 Jovin Ganda Ramdhan, Sumiyati. Perlindungan Hukum Terhadap Nasabah Korban Skimming Ditinjau Dari Undang-Undang Nomor 8 Tahun 1999. Mimbar Keadilan Volume 12 Nomor 1 Februari 2019 - Juli 2019. Hal. 85
} 
bahan hukum primer yang terdiri dari peraturan perundang-undangan, bahan hukum sekunder berupa buku-buku, dan bahan hukum tersier yaitu bahan lain yang ada relevansinya dengan pokok permasalahan yang memberikan informasi tentang bahan hukum primer dan sekunder. Data dikumpulkan dengan cara studi dokumen dan wawancara yang kemudian dianalisis dengan metode yuridis kualitatif yang kemudian disusun secara kualitatif untuk mencapai kejelasan masalah yang dibahas.

\section{PEMBAHASAN}

\section{Perlindungan Hukum terhadap Nasabah Korban Duplikasi Data Bank Ditinjau dari Undang-Undang No. 10 Tahun 1998 Tentang Perbankan}

Perlindungan nasabah perbankan merupakan salah satu permasalahan yang sampai saat ini belum mendapatkan tempat yang baik di dalam sistem perbankan nasional.6 Seringkali terjadi dalam kenyataan, bahwa nasabah selalu dianggap lemah atau pada posisi yang kurang diuntungkan apabila terjadi kasus-kasus perselisihan antara bank dengan nasabahnya, sehingga nasabah dirugikan. ${ }^{10}$

Dengan segala kemajuan teknologi yang ada bank menciptakan sebuah alat teknologi yang dimana bisa memudahkan konsumen untuk melakukan transaksi tanpa harus mendatangi teller yaitu melalui mesin ATM. Dalam kartu ATM ini terdapat pita magnetic (Magnetic stripe) biasanya tertulis data pribadi pemegang kartu dalam bentuk kode-kode tertentu yang hanya bisa dibaca oleh computer dan dilengkapi dengan mesin pembaca magnetic stripe. Perjanjian penggunaan kartu ATM dibuat dalam bentuk perjanjian baku, yang mana perjanjian terjadi dengan cara pihak menyiapkan syarat-syarat yang baku pada suatu formulir perjanjian yang sudah dicetak dan kemudian diberikan kepada pihak lainnya untuk dapat disetujui dengan hampir tidak dapat memberikan kebebasan sama sekali kepada pihak lainnya untuk melakukan negosiasi atas syarat-syarat yang diberikan tersebut.

\footnotetext{
${ }^{10}$ Ibid.,
} 
Penggunaan kartu ATM selain memberikan manfaat tentu juga mempunyai risiko, yaitu dengan mudahnya pembobolan simpanan nasabah yang salah satunya dengan menggunakan modus skimming. Skimming adalah sebuah modus penggaandaan data kartu nasabah pada saat transaksi di ATM karena telah di pasang alat skimmer di depan mulut card reader. Dengan menggunakan alat skimmer yang di rancang sedemikian rupa sehingga menyerupai bentuk dari card reader. Dengan modus skimming ini informasi yang tersimpan secara magnetis pada kartu ATM dapat diduplikasi melalui perangkat khusus yang di tempatkan di mulut kartu ATM yang kemudian disalin pada kartu duplikat. Setelah kartu di duplikat seorang tersebut bisa langsung menggunakan untuk transaksi seperti penarikan uang serta melakukan transfer uang dengan cepat sehingga nasabah pada umumnya tidak menyadarinya jika telah terkena skimming.

Kemajuan teknologi yang begitu pesat di dunia perbankan sendiri sebenarnya kurang begitu terdukung dengan peraturan perundangundangan terkait perbankan yang ada sekarang. Adapun tindak pidana yang diatur dalam dalam Undang-Undang Republik Indonesia Nomor 7 Tahun 1992 Tentang Perbankan, Lembaran Negara Republik Indonesia Tahun 1992 Nomor 32, Tambahan Lembaran Negara Republik Indonesia Nomor 3473, sebagaimana telah diubah dengan Undang-Undang Republik Indonesia Nomor 10 Tahun 1998 Tentang Perubahan Atas Undang-Undang Nomor 7 Tahun 1992 Tentang Perbankan, Lembaran Negara Republik Indonesia Tahun 1998 Nomor 182, Tambahan Lembaran Negara Republik Indonesia Nomor 3790 (selanjutnya disebut UndangUndang Perbankan) dan UndangUndang No.21 Tahun 2008 tentang Perbankan Syariah, Lembaran Negara Republik Indonesia Tahun 2008 Nomor 94, Tambahan Lembaran Negara Republik Indonesia Nomor 4867 (selanjutnya disebut UndangUndang Perbankan Syariah) adalah:
a. Tindak pidana berkaitan dengan perizinan;
b. Tindak pidana berkaitan dengan rahasia bank;
c. Tindak pidana berkaitan dengan pengawasan bank; 
d. Tindak pidana berkaitan dengan kegiatan usaha bank;

e. Tindak pidana berkaitan dengan pihak terafiliasi;

f. Tindak pidana berkaitan dengan pemegang saham;

g. Tindak pidana berkaitan dengan ketaatan terhadap ketentuan. ${ }^{11}$

Pengaturan terkait pidana tersebut hanya mengatur terkait perbuatanperbuatan yang dilakukan oleh pihak bank atau pihak terafiliasi. Yang dimaksud Pihak Terafiliasi menurut Pasal 1 angka 22 Undang-Undang Perbankan adalah anggota dewan komisaris, pengawas, direksi atau kuasanya, pejabat, atau karyawan bank; anggota pengurus, pengawas, pengelola atau kuasanya, pejabat, atau karyawan bank, khusus bagi bank yang berbentuk hukum koperasi sesuai dengan peraturan perundangundangan yang berlaku; pihak yang memberikan jasanya kepada bank, antara lain akuntan publik, penilai, konsultan hukum dan konsultan lainnya; dan pihak yang menurut penilaian Bank Indonesia (saat ini OJK) turut serta mempengaruhi pengelolaan bank, antara lain pemegang saham dan keluarganya, keluarga komisaris, keluarga pengawas, keluarga direksi, keluarga pengurus.

Undang-Undang Nomor 10 Tahun 1998 tentang Perbankan dapat dikatakan tidak memuat secara terperinci ketentuan mengenai perlindungan hukum bagi nasabah bank. Pada Pasal 29 ayat (5) Undang-Undang Nomor 7 Tahun 1992 yang sebagaimana diubah oleh UndangUndang Nomor 10 Tahun 1998 tentang Perbankan disebutkan: "Untuk kepentingan nasabah, bank menyediakan informasi mengenai kemungkinan timbulnya resiko kerugian bagi transaksi nasabah yang dilakukan melalui bank".

Pada pasal tersebut dpat dikatakan bahwa sedikit penjelasan mengenai perlindungan hukum terhadap nasabah bank. Penjelasan pasal tersebut tidak memuat pengertian dan penjelasan secara menyeluruh mengenai apa dan bagaimana kepentingan nasabah yang tidak boleh dirugikan. Undang-undang perbankan tersebut hanya memberikan perlindungan hukum kepada

\footnotetext{
${ }^{11}$ Otoritas Jasa Keuangan, Pahami dan Hindari: Buku Memahami dan Menghindari Tindak Pidana Perbankan (OJK 2016). Hal. 9-10
} 
nasabah penyimpan bahwa simpanannya dijamin oleh bank melalui pembentukan lembaga penjamin simpanan masyarakat yang bersifat permanen, sebagaimana tertuang dalam Pasal 37 B UndangUndang Nomor 10 Tahun 1998.

Rumusan Pasal 37 B ayat (1) Undang-Undang Nomor 10 Tahun 1998:

1. Setiap bank wajib menjamin dana masyarakat yang disimpan pada bank yang bersangkutan.

2. Untuk menjamin simpanan masyarakat pada bank sebagaimana dimaksud dalam ayat (1) dibentuk Lembaga Penjamin Simpanan.

3. Lembaga Penjamin Simpanan sebagaimana dimaksud dalam ayat (2) berbentuk badan hukum Indonesia.

4. Ketentuan mengenai penjamin dana masyarakat dan Lembaga Penjamin Simpanan, diatur lebih lanjut dengan Peraturan Pemerintah.

Lembaga Penjamin Simpanan (LPS) merupakan badan hukum yang mempunyai kedudukan sebagai lembaga yang independen, transparan, dan akuntabel dalam melaksanakan tugas dan wewenangnya. Fungi dari dibentuknya LPS yaitu menjamin simpanan nasabah penyimpan dan turut aktif dalam memelihara stabilitas sistem perbankan sesuai dengan kewenangannya.

\section{Bagaimana Perlindungan Hukum terhadap Nasabah Korban}

\section{Duplikasi Data Bank Ditinjau dari Undang-Undang No. 11 Tahun}

\section{Tentang Informasi Dan Transaksi Elektronik}

Teknik Skimming dapat dibagi kedalam segmen sebagai berikut:

a. Memperoleh data nasabah;

b. Membuat kartu elektronik palsu; dan

c. Melakukan transaksi dengan menggunakan kartu elektronik palsu.

Perbuatan memperoleh data nasabah dengan menggunakan Skimmer sesuai dengan Pasal 46 ayat (2) UU ITE yang berbunyi sebagai berikut: “(2). Setiap Orang yang memenuhi unsur sebagaimana dimaksud dalam Pasal 30 
ayat (2) dipidana dengan pidana penjara paling lama 7 (tujuh) tahun dan/atau denda paling banyak Rp700.000.000,00 (tujuh ratus juta rupiah)”.

Pasal 46 ayat (2) UU ITE tersebut menjelaskan perbuatan memperoleh Informasi Elektronik dan/atau Dokumen Elektronik berbunyi sebagai berikut: “(2). Setiap Orang dengan sengaja dan tanpa hak atau melawan hukum mengakses Komputer dan/atau Sistem Elektronik dengan cara apa pun dengan tujuan untuk memperoleh Informasi Elektronik dan/atau Dokumen Elektronik".

Perbuatan yang diuraikan dalam Pasal 30 ayat (2) UU ITE tersebut dapat dijabarkan kedalam unsur-unsur sebagai berikut:

a. Sengaja;

b. Tanpa hak atau melawan hukum;

c. Mengakses Komputer dan/atau Sistem Elektronik; dan

d. Tujuan untuk memperoleh Informasi Elektronik dan/atau Dokumen Elektronik.

Terkait dengan unsur kesengajaan sebenarnya menjelaskan terkait dengan bentuk kesalahan pada delik yang diatur. Pengaturan terhadap bentuk kesalahan secara jelas ini berarti pembentukan pasal ini dilakukan dengan padangan monistis, dimana dalam perbuatan pidana (Strafbaar feit) unsur perbuatan dan unsur kesalahan merupakan satu kesatuan. ${ }^{12}$ Kesalahan sendiri harus lah memiliki kesengajaan (Dolus) atau kealpaan (Culpa). ${ }^{13}$

Pada Skimming, perbuatan memperoleh data pribadi nasabah memiliki sifat melawan hukum yang jelas dimana melanggar ketentuan peraturan perundang-undangan. Pelanggaran yang menimbulkan sifat melawan hukum tersebut perlu diperhatikan Pasal 26 ayat (1) UU ITE yang berbunyi:

“(1). Kecuali ditentukan lain oleh peraturan perundang-undangan, penggunaan setiap informasi melalui media elektronik yang menyangkut data pribadi seseorang harus dilakukan atas persetujuan Orang yang bersangkutan".

\footnotetext{
${ }^{12}$ Lexy Fatharany Kurniawan, Penegakan Hukum Tindak Pidana Kartu Kredit. Skripsi. Fakultas Hukum Universitas Airlangga. 2006. Hal. 43.

${ }^{13}$ Ibid., Hal. 63
} 
Sehingga jelas bahwa pada perolehan data nasabah dilakukan secara tanpa hak dan juga melawan hukum. Unsur mengakses Komputer dan/atau Sistem Elektronik merupakan unsur perbuatan dalam tindak pidana yang diatur. Pasal 1 angka 14 UU ITE mendefinisikan "Komputer adalah alat untuk memproses data elektronik, magnetik, optik, atau sistem yang melaksanakan fungsi logika, aritmatika, dan penyimpanan".

Pasal 1 angka 5 UU ITE

"Sistem Elektronik adalah serangkaian perangkat dan prosedur elektronik yang berfungsi mempersiapkan, mengumpulkan, mengolah, menganalisis, menyimpan, menampilkan, mengumumkan, mengirimkan, dan/atau menyebarkan Informasi Elektronik".

Mengingat kartu elektronik dalam hal ini adalah Alat Pembayaran Menggunakan Kartu (APMK) maka kartu elektronik tersebut merupakan surat berharga berdasarkan Kitab Undang-Undang Hukum Dagang, ${ }^{14}$ hal ini mengindikasikan jelas bahwa hal dilakukan pemalsuan fisik kartu elektronik pada teknik Skimming merupakan tindak pidana (Delik) dalam Pasal 263 Kitab UndangUndang Hukum Pidana (KUHAP). Terkait pemalusan data pada kartu palsu merupakan pemalsuan yang terkait dengan komputer sehingga menggunakan Pasal 51 ayat (1) UU ITE.

Pada transaksi atas nama nasabah menggunakan kartu elektronik palsu melibatkan baik mesin ATM ataupun mesin debet, yang dapat diartikan sebagai Komputer, jaringan Komputer, dan/atau media elektronik lainnya dalam definisi transaksi elektronik dalam Pasal 1 angka 2 Undang-Undang Informasi dan Transaksi Elektronik. Karena transaksi tersebut merupakan Transaksi Elektronik, maka cara transaksi dilakukan merupakan interaksi dan/atau pertukaran Informasi Elektronik dan/atau Dokumen Elektronik

\footnotetext{
${ }^{14}$ Sri Yunengsih Utama. Perlindungan Hukum Terhadap Pemegang Kartu Kredit Sebagai Akibat Penyalahgunaan Kartu Kredit Dalam Transaksi Perdagangan. Thesis. Fakultas Hukum Universitas Pasundan. 2013. Hal. 2
} 
sebagaimana diatur dalam Pasal 17 ayat (2) Undang-Undang Informasi dan Transaksi Elektronik.

\section{SIMPULAN}

1. Undang-Undang Nomor 10 Tahun 1998 tentang Perbankan dapat dikatakan tidak memuat secara terperinci ketentuan mengenai perlindungan hukum bagi nasabah bank. Undang-undang perbankan tersebut hanya memberikan perlindungan hukum kepada nasabah penyimpan bahwa simpanannya dijamin oleh bank melalui pembentukan lembaga penjamin simpanan masyarakat yang bersifat permanen, sebagaimana tertuang dalam Pasal 37 B.

2. Perlindungan hukum terhadap nasabah korban duplikasi data bank ditinjau dari Undang-Undang No. 11 Tahun 2008 Tentang Informasi Dan Transaksi Elektronik tertuang dalam Pasal 46 ayat (2). Selain itu, pada transaksi atas nama nasabah menggunakan kartu elektronik palsu dengan teknik Skimming merupakan tindak pidana (Delik) dalam Pasal 263 Kitab UndangUndang Hukum Pidana (KUHAP). Terkait pemalusan data pada kartu palsu merupakan pemalsuan yang terkait dengan komputer sehingga menggunakan Pasal 51 ayat (1) UU ITE.

\section{SARAN}

1. Lemahnya perlindungan hukum berdasarkan UU perbankan dan UU ITE perlu dikaji dan dilakukan singkronisasi dengan peraturan perundang-undangan lain yang mengedepankan perlindungan nasabah terhadap kejahatan siber.

2. Perlindungan terhadap nasabah korban kejahatan skimming dapat dilakukan dalam konteks penegakan hukum pidana dan penegakan hukum perdata, namun juga memerlukan dukungan dari berbagai pihak terutama masyarakat sendiri yang harus diberikan edukasi 
secara simultan, karena kejahatan yang terus berkembang baik Teknik maupun modus operandinya.

\section{DAFTAR PUSTAKA}

Adrian Sutedi, Hukum Perbankan, Sinar Grafika, Jakarta, 2006

E. Syaefullah, Beberapa Masalah Pokok Tentang Tanggung Jawab Pengangkutan Udara, LLPM Universitas Islam Bandung, Bandung, 1999

Funir Fuady, Hukum Perbankan Modern, Buku Kesatu, Penerbit PT. Citra Aditya Bakti, Bandung, 2003

Hermansyah, Hukum Perbankan Nasional Indonesia, Prenada Media Group, Jakarta, 2006

Johannes Ibrahim, Bank Sebagai Lembaga Intermediasi Dalam Hukum Positif, CV. Utomo, Bandung, 2004

Kasmir, Manajemen Perbankan, PT Raja Grafindo Persada, Jakarta, 2000

Lukman Dendiwijaya, Manajemen Perbankan, Ghalia Indonesia, Jakarta, 2000

Muhamad Djumhana, Hukum Perbankan di Indonesia, Citra Aditya Bakti, Bandung, 2006

Muchdarsyah Sinungan, Uang dan Bank, Bina Aksara, Jakatra, 1987

O.P. Simorangkir, Kamus Perbankan, Cetakan Kedua, Bina Aksara, Jakarta ,1989

Sentosa Senbiring, Hukum Perbankan, Mandar Maju, Bandung, 2000

Sophar Lumbantoruan, Akuntansi Pajak, PT. Gramedia Widia Sarana Indonesia, Jakatra, 1996

Widjanarto, Hukum dan Ketentuan Perbankan di Indonesia, Grafiti, Jakarta, 2003

\section{UNDANG-UNDANG}

Kitab Undang-Undang Hukum Perdata 
Undang-Undang No.7 tahun 1992 Tentang Perbankan

Undang-Undang No.10 tahun 1998 Tentang Perubahan Atas UU No.7 Tahun 1992 Tentang Perbankan

Undang-Undang No 23 tahun 1999 Tentang Bank Indonesia

Undang-Undang N0 24 Tahun 1999 Tentang Lalu Lintas Devisa dan Sistem Nilai Tukar

Undang-Undang No 3 tahun 2004 Tentang Perubahan atas Undang-Undang No 23 Tahun 1999 Tentang Bank Indonesia

Peraturan Pemerintah Nomor 25 Tahun 1999 Tentang Pencabutan Izin Usaha, Pembubaran dan Likuidasi Bank

\section{SUMBER LAIN}

Neni Sri Imaniyati, Pencucian Uang (Money Laundering) Dalam Perspektif Hukum Perbankan dan Hukum Islam, Jurnal Sosial dan Pembangunan, Volume XXI No. I th 2005

Buletin Hukum Perbankan Dan Kebanksentralan Direktorat Hukum Bank Indonesia Vol 2, No 3, Desember 2004

Erick, Priberkah, Seputar Indonesia

Tempo Interaktif, Bandung

Timbuktu Harthana, Kompas, 13 September- 2007

Yedi, Pikiran Rakyat, 7 Desember 2007

Lihat <http ://www.bi.go.id/ Bank Dalam Pengawasan Khusus (Special

Surveillance)> di-browse oleh penulis tanggal 8 Desember 2007

Hppt://www.detikfinance.com/index/php/detik.read/tahun/2007/bulan/1

$2 / \operatorname{tgl} / 07$ 